\section{A Fruit Quality Survey of Peach Cultivars Grown in the Southeastern United States}

\author{
Catherine Belisle ${ }^{1}$, Uyen T.X. Phan ${ }^{2,3}$, Koushik Adhikari ${ }^{2}$, and \\ Dario J. Chavez ${ }^{1,4}$
}

ADDITIONAL INDEX WORDs. titratable acidity, firmness, color space, soluble solids concentration, total titratable acidity, puncture, compression, Kramer shear

Summary. Peach (Prunus persica) production in the southeastern United States extends from mid-May to mid-September. There are $\approx 60$ peach cultivars commercially grown. Each cultivar has unique fruit quality characteristics, which could influence consumer perception and likability. The present study is a survey of chemical and physical characteristics of mature, commercially grown, fresh peaches in Georgia. A collection of 30 cultivars was evaluated in 2015 and 2016 for soluble solids concentration (SSC), total titratable acidity (TTA), SSC/TTA ratio, texture (compression, puncture, and Kramer shear), and skin and flesh color (CIE $L^{*}$, chroma, and hue color space values). There was significant variation between seasons for all variables $(P<0.05)$ except for TTA $(P=0.12)$, and flesh hue values $(P=0.38)$. Statistical differences among cultivars within each year were reported for all variables $(P<0.0001)$. SSC showed variation seasonally and among cultivars, whereas TTA variation was mainly attributed to cultivar differences. Similarly, cultivar-to-cultivar differences were found when comparing the different texture tests evaluated with cultivars such as Goldprince, Early August Prince, Flameprince, Majestic, and Red Globe having the most variation between seasons. Other cultivars analyzed had little variation between seasons. Moreover, firmness differences observed across the three texture tests were inconsistent. In peach skin color, significant variation was observed for $L^{*}$, chroma, and hue among cultivars. Skin hue and chroma were highly correlated within each season $(r=0.77$ for 2015 , $r=0.72$ for 2016). The results of this survey demonstrate the variation of quality characteristics for a large selection of peach cultivars grown in Georgia. The information reported in this paper will be used as a baseline for further examining and understanding peach fruit quality.

$\mathrm{P}$ each in the southeastern United States is one of the most important fruit commodities. South Carolina and Georgia rank second and third nationally in peach production in the United States, respectively (U.S. Department of Agriculture, 2017). Per capita consumption per year of fresh peaches in the United States has been in decline from $5.3 \mathrm{lb}$ in 1995 to $3.1 \mathrm{lb}$ in 2015 (U.S. Department of Agriculture, 2016). This decline has been primarily associated with consumer disapproval of fresh peach quality (Crisosto et al.,

We thank Malgosia Florkowska, Glenn Farrell, Mary Sutton, Luis Monserrate, and Gray Strickland for their help, Pearson Farm and Lane Southern Orchards for supplying produce, and the Georgia Peach Council and the Georgia Peach Commission for their support.

${ }^{1}$ Department of Horticulture, University of Georgia, Griffin Campus, Griffin, GA 30223

${ }^{2}$ Department of Food Science, University of Georgia, Griffin Campus, Griffin, GA 30223

${ }^{3}$ Institute of Biotechnology and Food Technology, Industrial University of Ho Chi Minh City, Ho Chi Minh City, Vietnam 700000

${ }^{4}$ Corresponding author. E-mail: dchavez@uga.edu.

https://doi.org/10.21273/HORTTECH03870-17
2006). Peach appearance and aroma are the initial indicators used by consumers to purchase fresh peaches, whereas repeat purchases are because of flavor and texture perceptions of the fruit previously consumed (Baldwin, 2002; Bruhn, 1995; Bruhn et al., 1991; Delgado et al., 2013; Diehl et al., 2013). For appearance, color is the characteristic commonly associated with fruit maturity. In commercial peach production systems, fruit appearance is the first factor evaluated by field workers using skin redness (foreground color) and background color and firmness as the reference distinctions to determine optimal fruit maturity at harvest (Crisosto and Valero, 2008).

Most peach fruit quality research has been focused on measuring SSC and TTA (Echeverria et al., 2012), with SSC used as a sweetness indicator and TTA as a sourness indicator. These quality indicators vary across different fresh peach production areas. Quality standards for yellowflesh peaches in California have been set at a minimum of $10 \%$ SSC (Kader, 1995). In Italy, 10\% SSC is the suggested quality minimum for early season, $11 \%$ for midseason, and $12 \%$ for late-season peaches (Testoni, 1995; Ventura et al., 2000). In France, a quality index was also developed for low-acidity peaches with $10 \%$ SSC and TTA $<0.9 \%$, and for high-acid peaches with $11 \%$ SSC and TTA $>0.9 \%$, according to Hilaire (2003). However, human taste is not primarily driven by SSC, it is rather a combination of sweet and sour sensations produced by sugars and organic acids (Sanz and Perez, 2010). In addition, the use of the sugar/acid ratio has been proposed as a measurement of acceptable flavor quality when kept above a minimum SSC and below a set maximum TTA (Kader, 2002), both of which are dependent on consumer preferences in each region.

Texture is an additional quality characteristic and one that can vary drastically based on the maturity of the peaches and between cultivars. Peaches are known for their textural differences, including "melting" and "non-melting" flesh types. Melting flesh peaches have a distinctive softening in the final stage of ripening that continues through senescence, whereas non-melting flesh peaches do not (Bassi and Monet, 2008). Melting flesh types have been reported

\begin{tabular}{llll}
\hline $\begin{array}{l}\text { Units } \\
\begin{array}{l}\text { To convert U.S. to SI, } \\
\text { multiply by }\end{array}\end{array}$ & U.S. unit & SI unit & $\begin{array}{l}\text { To convert SI to U.S., } \\
\text { multiply by }\end{array}$ \\
\hline 29,574 & $\mathrm{fl} \mathrm{oz}$ & $\mu \mathrm{L}$ & $3.3814 \times 10^{-5}$ \\
29.5735 & $\mathrm{fl} \mathrm{oz}$ & $\mathrm{mL}$ & 0.0338 \\
2.54 & inch $(\mathrm{es})$ & $\mathrm{cm}$ & 0.3937 \\
25.4 & inch $(\mathrm{es})$ & $\mathrm{mm}$ & 0.0394 \\
0.4536 & $\mathrm{lb}$ & $\mathrm{kg}$ & 2.2046 \\
0.4536 & $\mathrm{lbf}$ & $\mathrm{kgf}$ & 2.2046 \\
0.0160 & $\mathrm{lbf} / \mathrm{oz}$ & $\mathrm{kgf} \cdot \mathrm{g}^{-1}$ & 62.5000 \\
28.3495 & $\mathrm{oz}$ & $\mathrm{g}$ & 0.0353 \\
$\left({ }^{\circ} \mathrm{F}-32\right) \div 1.8$ & ${ }^{\circ} \mathrm{F}$ & ${ }^{\circ} \mathrm{C}$ & $\left({ }^{\circ} \mathrm{C} \times 1.8\right)+32$
\end{tabular}


as softer and juicier in texture, compared with non-melting types that have been reported as harder and less juicy (Brovelli et al., 1999). The use of different textural tests, such as compression, puncture, and Kramer shear, have been previously reported in peaches and can be used to classify these flesh differences (Bourne, 1974).

Most fruit quality studies in peach have focused on individual quality characteristics such as texture, aroma, color, size, sugar concentration, and acidity (Contador et al., 2015; Crisosto and Crisosto, 2005; Fallahi et al., 2009a, 2009b; Visai and Vanoli, 1997). A collection of observable quality descriptors for individual cultivars is yet to be established for the southeastern United States. These traits may include shape, skin and flesh color, texture type, volatile profile, and sugar and acid concentration. A survey of the quality characteristics for a large collection of fresh peaches would allow understanding the variation present within the southeastern U.S. peach production. In addition, creating a survey of information would allow more in-depth research in preharvest and postharvest management, the genetic component of quality, and which quality characteristics define consumer preference and likeness. This is the first report of a series of studies being done at the University of Georgia in understanding fresh peach fruit quality in the southeastern United States.

\section{Materials and methods Plant material}

Thirty commercial peach cultivars were used in this study (Table 1 ). Peach samples were collected from May to August in 2015 and 2016 representing early-, mid-, and late-season cultivars grown in the southeastern United States. Fruit were harvested and graded following standard commercial procedures by one commercial grower in Fort Valley, GA. Commercial standards consisted of fruit being harvested and graded by field workers for appearance and firmness as the main attributes. Our objective was to obtain a sample set comparable with marketed fresh peaches with no additional grading done to peaches based on ethylene production or maturity index. Graded peaches were packed in 25-lb commercial boxes and stored at 7 to $10{ }^{\circ} \mathrm{C}$ for $1-3 \mathrm{~d}$ until transported on ice to the University of Georgia's Food Science Pilot Plant, Griffin, GA. The samples were then stored at $4{ }^{\circ} \mathrm{C}$ for $3 \mathrm{~d}$. Before evaluation, samples were moved to room temperature $\left(22^{\circ} \mathrm{C}\right)$ for $2-3 \mathrm{~d}$ to allow fruits to ripen. Cold storage and ripening procedures followed practices used in supermarkets and produce stores to ensure a standardized, readyto-eat product. Bruised and damaged

Table 1. Fruit characteristics and harvests dates of commercial peach cultivars grown in Georgia included in this study of fruit quality.

\begin{tabular}{|c|c|c|c|c|c|c|}
\hline \multirow[b]{2}{*}{ Cultivar } & \multirow[b]{2}{*}{ Flesh type } & \multirow[b]{2}{*}{ Pit adherence } & \multirow[b]{2}{*}{ Flesh color } & \multirow[b]{2}{*}{ Acidity } & \multicolumn{2}{|c|}{ Harvest date ${ }^{\mathrm{z}}$} \\
\hline & & & & & 2015 & 2016 \\
\hline Augustprince & Melting & Freestone & Yellow & Standard & 29 July & 12 July \\
\hline Caro King & Melting & Semifreestone & Yellow & Standard & 17 June & 15 June \\
\hline Carored & Melting & Clingstone & Yellow & Standard & 22 May & 18 May \\
\hline Early August Prince & Melting & Freestone & Yellow & Standard & 17 July & 12 July \\
\hline Flameprince & Melting & Freestone & Yellow & Standard & 5 Aug. & 29 July \\
\hline Flavorich & Melting & Clingstone & Yellow & Standard & 12 May & 14 May \\
\hline Gala & Melting & Semifreestone & Yellow & Standard & 2 June & 2 June \\
\hline Elberta & Melting & Freestone & Yellow & Standard & 23 June & 23 June \\
\hline Goldprince & Melting & Clingstone & Yellow & Standard & 26 May & 26 May \\
\hline Majestic & Melting & Freestone & Yellow & Standard & 26 June & 23 June \\
\hline Red Globe & Melting & Freestone & Yellow & Standard & 2 July & 6 July \\
\hline Rich Lady & Non-melting & Semifreestone & Yellow & Standard & 11 June & 9 June \\
\hline Rich Pride & Non-melting & Clingstone & Yellow & Standard & 11 June & 8 June \\
\hline Rubyprince & Melting & Clingstone & Yellow & Standard & 2 June & 27 May \\
\hline Ruston Red & Melting & Freestone & Yellow & Standard & 7 July & 7 July \\
\hline Scarletprince & Melting & Freestone & Yellow & Standard & 2 July & 30 June \\
\hline Sierra Rich & Melting & Freestone & Yellow & Standard & 18 June & 16 June \\
\hline Springflame21 & Non-melting & Clingstone & Yellow & Standard & 26 May & 19 May \\
\hline Springprince & Non-melting & Clingstone & Yellow & Standard & 21 May & 18 May \\
\hline Summerflame & Melting & Freestone & Yellow & Standard & 31 July & 14 July \\
\hline
\end{tabular}

${ }^{\mathrm{z}}$ Commercial harvest dates provided by producer in Fort Valley, GA 
fruit were removed from cultivar samples following similar procedures practiced in the fresh retail markets. Graded peaches were used for further analyses. Of the 30 peach cultivars used in this study, 25 were melting and five were non-melting flesh cultivars. In addition, cultivars used in this study could be further classified into three pit adherence categories: clingstone (nine cultivars), semifreestone (five cultivars), and freestone (16 cultivars). Twentynine peach cultivars were yellow-flesh and one white-flesh; with 29 having standard acidity and one being low acid (also known as honey) (Table 1).

\section{Soluble solids concentration and TTA measurements}

Juice PREPARATION. Flesh with skin from five representative ripened, graded peaches per cultivar were separated from their pits, quartered and stored in a freezer-safe plastic bag (Ziploc $^{\circledR}$; SC Johnson, Racine, WI) at $-80^{\circ} \mathrm{C}$ in an ultra-low freezer (U725 INNOVA; Eppendorf, Hauppauge, $\mathrm{NY}$ ) until further processing. Frozen samples were thawed at $4{ }^{\circ} \mathrm{C}$ for $24 \mathrm{~h}$ and representative fruit samples per bag were puréed for $\approx 5 \mathrm{~min}$ in a food blender (Ninja Ultima Blender BL810 series; Balance, Cleveland, $\mathrm{OH}$ ). Three replications of $33 \mathrm{~g}$ of the peach purée per cultivar were weighed and poured in a $50-\mathrm{mL}$ centrifuge tube (Oak Ridge Nalgene; Thermo Scientific, Waltham, MA). Tubes were then centrifuged at $18,824 g_{\mathrm{n}}$ at $5{ }^{\circ} \mathrm{C}$, for $20 \mathrm{~min}$, in a centrifuge (5810R; Eppendorf). The supernatant was filtered and collected using a precut, four-layered, cheesecloth, $95 \times 95 \mathrm{~mm}$ (VWR, Radnor, PA). The total volume of the filtered juice obtained per replication per cultivar was measured and poured in a $15-\mathrm{mL}$ conical tube and stored at $-20{ }^{\circ} \mathrm{C}$ for later processing.

JuICE ANALYSES. The 15-mL conical tubes were thawed on benchtop at room temperature $\left(20\right.$ to $\left.22^{\circ} \mathrm{C}\right)$ for $1 \mathrm{~h}$. The tubes were then vortexed before sampling. SSC was measured using $300 \mu \mathrm{L}$ of peach juice in a digital refractometer (PR-32 palette; Atago, Tokyo, Japan). TTA was measured using a solution of $6 \mathrm{~mL}$ of peach juice diluted in $50 \mathrm{~mL}$ of deionized water $(\mathrm{pH}=$ 7.0) with the titrator (Easy PRO, Easy plus; Mettler Toledo, Greifensee, Switzerland) using $0.1 \mathrm{~N}$ sodium hydroxide $(\mathrm{NaOH})$ as titrant. Initial $\mathrm{pH}$, volume $(\mathrm{mL})$ of $0.1 \mathrm{~N} \mathrm{NaOH}$, and TTA were calculated as described by Mitcham et al. (1996) using an endpoint titration $\mathrm{pH}$ of 8.2 and an acid milliequivalent factor of 0.067 for malic acid. Three juice samples corresponding to the initial three puree samples per cultivar were read for TTA and SSC as replications.

\section{Texture analyses}

Puncture, compression, and Kramer shear measurements were made using an Instron universal testing machine (model 1122; Instron Corp., Canton, MA) using graded peach fruit ripened at room temperature as previously described. Puncture was expressed as kilogram force (kgf), and compression and Kramer were expressed as kilogram force per gram $\left(\mathrm{kgf} \cdot \mathrm{g}^{-1}\right)$. For puncture, the top $1-2 \mathrm{~mm}$ of fruit skin and flesh surface were removed using a stainless steel blade. Once removed, puncture measurements were conducted using a 7.9-mm-diameter probe to penetrate the peach flesh at a depth of $8 \mathrm{~mm}$. This protocol was adapted from Shinya et al. (2013). The probe ran at a speed of $5 \mathrm{~mm} \cdot \mathrm{min}^{-1}$. Measurements were taken both in the blush and light side of each fruit for a total of five fruit per cultivar.

For compression, peach flesh was cut into a $10 \times 15-\mathrm{mm}$ (height $\times$ diameter) cylindrical shape and placed on a $15-\mathrm{cm}$ flat horizontal plate attached to an inverted load cell. A $4-\mathrm{cm}$ plate was then attached to the moving crosshead. The crosshead speed was set at $50 \mathrm{~mm} \cdot \mathrm{min}^{-1}$. The moving plate compressed the sample vertically from a starting point of 10 to $2 \mathrm{~mm}$ height, then retreated back to the starting position (10 $\mathrm{mm}$ height) and the compression was repeated. Thus, each sample was subjected to two "bites." The compression protocol was adapted from Bourne (1968). Fruit flesh cores were taken from both the blush and light side of each fruit for a total of five fruit per cultivar.

Kramer shear, a 70-mm-wide upper blade with ten 3 -mm-thick blades was used to shear the sample held in a standard cell (catalog 2830-018; Instron Corp.). Fifty grams $( \pm 1)$ of peach flesh per cultivar were added to the standard cell and placed in position for shear compression. A downward stroke set at $100 \mathrm{~mm} \cdot \mathrm{min}^{-1}$ vertically compressed the sample to a $46 \mathrm{~mm}$ depth. The Kramer shear protocol was adapted from Ahmed et al. (1972). A total of five replications per cultivar were measured.

\section{Color measurements}

Skin and flesh color were measured using a colorimeter (MiniScan XE; HunterLab, Reston, VA). A 3.5-cm-diameter ocular lens was used for each sample measurement. Values were taken in $\mathrm{C} / 2^{\circ} \mathrm{CIE}$ color space values of $L^{*}, a^{*}$, and $b^{*}$. The lightness coefficient, $L^{*}$, ranges from 0 (black) to 100 (white). Color space value $a^{*}$ ranges from positive (red) to negative (green) and $b^{*}$ ranges from positive (yellow) to negative (blue). Both $a^{*}$ and $b^{*}$ color values were used to calculate chroma $=$ square root $\left[\left(a^{*}\right)^{2}+\left(b^{*}\right)^{2}\right]$ and hue $=$ arctangent $\left(b^{*} / a^{*}\right)$ (degrees). Hereafter, only chroma and hue were used within this manuscript. Chroma (saturation or vividness) is reported as chromaticity increases a color becomes more intense and as it decreases a color becomes duller. Hue (tint of color) is an angular measurement where $0^{\circ}=\mathrm{red}, 45^{\circ}=$ orange-red, $90^{\circ}=$ yellow, $180^{\circ}=$ green, and $270^{\circ}=$ blue. The colorimeter was calibrated with a white MiniScan reference tile $(X=80.1, \Upsilon=85.1, Z=89.4$ for D65 $/ 10^{\circ}$; HunterLab). Peach color skin was evaluated on the blush and light side of the fruit. The same peach was then cut vertically, avoiding the peach pit, with the goal to capture the maximum surface area to measure the flesh color for the blush and light side of the fruit. Five fruit per cultivar were evaluated.

\section{Data analyses}

Analyses of variance were performed using the general linear model procedure in SAS software (version 9.2; SAS Institute, Cary, NC) to examine differences between cultivars and years. Differences among cultivars within a year were examined using Tukey's honestly significant difference test with a confidence level of 95\%. Pearson's pairwise correlations and regression analyses between the variables examined were analyzed using JMP Pro 12 software (SAS Institute). These methods were used to determine the relationships between variables within and across seasons.

\section{Results and discussion}

SOLUBLE SOLIDS CONCENTRATION AND TTA. Soluble solids concentration and TTA were evaluated for 30 
cultivars of peaches grown in Georgia for the 2015 and 2016 seasons (Table 1 ). There were statistical significant differences $(P \leq 0.05)$ when comparing data across seasons for SSC and SSC/ TTA, but not for TTA $(P=0.12)$. Differences among cultivars were identified for SSC, TTA, and SSC/ TTA $(P \leq 0.05)$. No statistical significant differences among replications were identified for SSC, TTA, and SSC/TTA $[P>0.05$ (data not shown)]. Because of the variation present across years, hereafter, all the analyses are based on within year comparisons, although, TTA from year 2015 and 2016 were not significantly different from each other.

Soluble solids concentration values ranged from $8.3 \%$ for 'Juneprince' to $15.6 \%$ for 'Summerflame' in 2015 and $8.4 \%$ for 'Carored' to $15.6 \%$ for 'Flameprince' in 2016 (Table 2). These values are similar to those reported by Contador et al.
(2011) with a range from $10.9 \%$ to $13.8 \%$ and Cantín et al. (2009) with a range of $7.6 \%$ to $17.5 \%$ for SSC. The variability of sugar concentration from year-to-year has been previously reported in peach and has been attributed to environmental effects, the inherent variation among cultivars, and the interaction of both factors (Cirilli et al., 2016). Climate and crop load are the major components that impact fruit quality variability (Culpepper and Caldwell, 1930), along with individual cultivar differences. In our study, cultivars varied slightly between years, with the highest variation in Summerflame with $15.6 \%$ SSC in 2015 to $12.1 \%$ SSC in 2016.

For TTA, values ranged from $0.26 \%$ for 'White Lady' to $1.11 \%$ for 'Flavorich' in 2015 to $0.22 \%$ for 'White Lady' to $0.75 \%$ for 'Juneprince' and 'Rich Pride' in 2016 (Table 2). Similar values were reported in Crisosto and Crisosto (2005) with ranges of $0.22 \%$ to $0.92 \%$, and in Contador et al. (2011) of $0.27 \%$ to $1.06 \%$. Reports have shown that TTA is unaffected much by growing conditions between seasons (Cirilli et al., 2016). The results from these studies further support our results and the lack of significant differences between the two seasons for TTA. In another aspect, acidity has been shown to be affected by fruit maturity (Ryugo and Davis, 1958). The highest variation for TTA between the two seasons for the 30 cultivars was reported in Flavorich with $1.11 \%$ in 2015 and $0.64 \%$ in 2016, whereas many cultivars showed little to no variation between seasons. In our study, no trends in TTA were identified when comparing data across years or whether the cultivar was harvested in early-, mid-, or late-season, other than standard acidity compared with low acidity (data not shown). The variation in fruit acidity has been

Table 2. Mean values for soluble solids concentration (SSC), total titratable acidity (TTA), and SSC/TTA ratio of 30 commercial peach cultivars included in this study over two seasons grown in Georgia.

\begin{tabular}{|c|c|c|c|c|c|c|}
\hline \multirow[b]{2}{*}{ Cultivar } & \multicolumn{2}{|c|}{ SSC (\%) } & \multicolumn{2}{|c|}{ TTA (\%) } & \multicolumn{2}{|c|}{ SSC/TTA (ratio) } \\
\hline & 2015 & 2016 & 2015 & 2016 & 2015 & 2016 \\
\hline Augustprince & $11.6 \mathrm{~h}-\mathrm{m}^{\mathrm{z}}$ & $14.1 \mathrm{~b}$ & $0.51 \mathrm{~g}-\mathrm{j}$ & $0.55 \mathrm{f}-\mathrm{i}$ & $23.2 \mathrm{c}-\mathrm{f}$ & $25.5 \mathrm{bc}$ \\
\hline Caro King & $11.3 \mathrm{j}-\mathrm{n}$ & $9.9 \mathrm{i}-1$ & $0.48 \mathrm{~h}-\mathrm{j}$ & $0.60 \mathrm{~d}-\mathrm{h}$ & $23.6 \mathrm{c}-\mathrm{e}$ & $16.4 \mathrm{~g}-\mathrm{n}$ \\
\hline Carored & $9.2 \mathrm{o}$ & $8.4 \mathrm{o}$ & $0.70 \mathrm{~b}-\mathrm{g}$ & $0.61 \mathrm{c}-\mathrm{h}$ & 12.9 no & $13.8 \mathrm{l}-\mathrm{O}$ \\
\hline Early August Prince & $11.8 \mathrm{~g}-1$ & $13.1 \mathrm{~cd}$ & $0.68 \mathrm{~b}-\mathrm{i}$ & $0.64 \mathrm{~b}-\mathrm{g}$ & $17.3 \mathrm{~h}-\mathrm{m}$ & $20.3 \mathrm{~d}-\mathrm{f}$ \\
\hline Fireprince & $13.0 \mathrm{~cd}$ & $10.0 \mathrm{i}-1$ & $0.63 \mathrm{~d}-\mathrm{i}$ & $0.55 \mathrm{f}-\mathrm{i}$ & $20.5 \mathrm{e}-\mathrm{h}$ & $18.3 \mathrm{e}-\mathrm{j}$ \\
\hline Flameprince & $12.6 \mathrm{c}-\mathrm{f}$ & $15.6 \mathrm{a}$ & $0.48 \mathrm{~h}-\mathrm{j}$ & $0.64 \mathrm{a}-\mathrm{g}$ & $25.9 \mathrm{bc}$ & $23.9 \mathrm{~b}-\mathrm{d}$ \\
\hline Flavorich & $11.11-\mathrm{n}$ & $9.5 \mathrm{k}-\mathrm{n}$ & $1.11 \mathrm{a}$ & $0.64 \mathrm{~b}-\mathrm{g}$ & $10.2 \mathrm{o}$ & $14.7 \mathrm{i}-\mathrm{O}$ \\
\hline Gala & $9.2 \mathrm{o}$ & $9.9 \mathrm{i}-1$ & $0.69 \mathrm{~b}-\mathrm{h}$ & $0.64 \mathrm{~b}-\mathrm{g}$ & $13.5 \mathrm{~m}-\mathrm{O}$ & $15.4 \mathrm{~h}-\mathrm{O}$ \\
\hline Goldprince & $11.1 \mathrm{k}-\mathrm{n}$ & $10.3 \mathrm{~h}-\mathrm{k}$ & $0.89 \mathrm{~b}$ & $0.65 \mathrm{a}-\mathrm{f}$ & 12.8 no & $15.6 \mathrm{~h}-\mathrm{O}$ \\
\hline Majestic & $14.1 \mathrm{~b}$ & $11.9 \mathrm{ef}$ & $0.50 \mathrm{~g}-\mathrm{j}$ & $0.54 \mathrm{f}-\mathrm{i}$ & $28.3 \mathrm{bc}$ & $21.9 \mathrm{c}-\mathrm{e}$ \\
\hline Red Globe & $11.9 \mathrm{f}-\mathrm{k}$ & $13.8 \mathrm{bc}$ & $0.62 \mathrm{~d}-\mathrm{i}$ & $0.54 \mathrm{f}-\mathrm{i}$ & $19.2 \mathrm{f}-\mathrm{k}$ & $25.3 \mathrm{bc}$ \\
\hline Rich Lady & $12.4 \mathrm{~d}-\mathrm{h}$ & $11.0 \mathrm{f}-\mathrm{h}$ & $0.79 \mathrm{~b}-\mathrm{e}$ & $0.74 \mathrm{ab}$ & $15.9 \mathrm{i}-\mathrm{n}$ & $14.9 \mathrm{~h}-\mathrm{O}$ \\
\hline Rich Pride & $12.8 \mathrm{c}-\mathrm{e}$ & $10.6 \mathrm{~g}-\mathrm{j}$ & $0.82 \mathrm{~b}-\mathrm{d}$ & $0.75 \mathrm{a}$ & $15.4 j-n$ & $14.4 \mathrm{j}-\mathrm{O}$ \\
\hline Rubyprince & $10.6 \mathrm{n}$ & $10.6 \mathrm{~h}-\mathrm{j}$ & $0.64 c-i$ & $0.64 \mathrm{a}-\mathrm{g}$ & $16.5 \mathrm{i}-\mathrm{n}$ & $16.4 \mathrm{~g}-\mathrm{n}$ \\
\hline Ruston Red & $13.3 \mathrm{bc}$ & $13.9 \mathrm{bc}$ & $0.47 \mathrm{i}-\mathrm{k}$ & $0.51 \mathrm{hi}$ & $28.4 \mathrm{bc}$ & $27.2 \mathrm{~b}$ \\
\hline Scarletprince & $12.2 \mathrm{e}-\mathrm{i}$ & $11.1 \mathrm{f}-\mathrm{h}$ & $0.66 \mathrm{c}-\mathrm{i}$ & $0.65 \mathrm{a}-\mathrm{f}$ & $17.8 \mathrm{~g}-1$ & $17.1 \mathrm{f}-\mathrm{m}$ \\
\hline Sierra Rich & $12.4 \mathrm{~d}-\mathrm{g}$ & $9.8 \mathrm{j}-\mathrm{m}$ & $0.73 \mathrm{~b}-\mathrm{f}$ & $0.59 \mathrm{e}-\mathrm{h}$ & $16.8 \mathrm{~h}-\mathrm{n}$ & $16.4 \mathrm{~g}-\mathrm{n}$ \\
\hline Springflame & $9.3 \mathrm{o}$ & $9.6 \mathrm{k}-\mathrm{n}$ & $0.63 \mathrm{~d}-\mathrm{i}$ & $0.72 \mathrm{a}-\mathrm{c}$ & $14.71-\mathrm{n}$ & $13.2 \mathrm{~m}-\mathrm{O}$ \\
\hline Springprince & 8.9 op & $9.21-0$ & $0.40 \mathrm{jk}$ & $0.55 \mathrm{f}-\mathrm{i}$ & $20.7 \mathrm{e}-\mathrm{h}$ & $16.9 \mathrm{f}-\mathrm{n}$ \\
\hline Summerflame & $15.6 \mathrm{a}$ & $12.1 \mathrm{e}$ & $0.62 \mathrm{~d}-\mathrm{j}$ & $0.67 \mathrm{a}-\mathrm{e}$ & $25.3 \mathrm{~b}-\mathrm{d}$ & $18.0 \mathrm{f}-1$ \\
\hline
\end{tabular}

${ }^{\mathrm{z}}$ Different letters within a column indicate significant difference between genotypes using Tukey's honestly significant difference test at $P \leq 0.05$. 
associated with cultivar type rather than by seasonal variation (Peynaud, 1950; Souty et al., 1967). In our study, White Lady was the only low-acid cultivar. These cultivars are characterized by having a higher gene expression of two particular genes (PRUpe and VP2) that allows vascular proton pumps to have an increased expression, producing proton leakage, and leading to lower accumulation of organic acids in the fruit (Etienne et al., 2002). Our study only evaluated one low-acid cultivar that made it difficult to characterize trends associated with lowacid cultivars and the instrumental variables measured.

The SSC/TTA ratio was calculated and values ranged from 10.2 for 'Flavorich' to 46.9 for 'White Lady' in 2015 and 12.0 for 'Zee Diamond' to 50.9 'White Lady' in 2016 (Table 2). Previous studies have linked consumer's sweetness perception with high SSC/ TTA values (Bassi and Selli, 1990; Colaric et al., 2005; Esti et al., 1997; Lopez et al., 2011; Ortiz et al., 2008). For instance, Colaric et al. (2005) found a positive correlation between sweetness and SSC/TTA ratio, where the cultivar with the lowest ratio was perceived as the sourest cultivar whereas the cultivar with the highest ratio was perceived as the sweetest cultivar. Because of the low acidity in 'White Lady', a standard-acidity peach cannot be compared with this cultivar using their ratio values. For instance, a $12.2 \%$ SSC with a standard acidity of $0.66 \%$ TTA, as found in 'Scarletprince', would yield a SSC/ TTA ratio of 17.8. In comparison, the low-acid cultivar White Lady with a similar SSC of $12 \%$ and a lower TTA at $0.22 \%$ would yield a SSC/ TTA ratio of 46.9. Although the SSC has little difference, the TTA value is shown to have a large impact on the ratio. The SSC/TTA ratio is biased in favor of low-acid cultivars when used to compare different acidity level cultivars types. Similar findings were reported in Crisosto and Crisosto (2005).

Texture. Puncture, compression, and Kramer shear measurements for 26 cultivars of peaches were measured for the 2015 and 2016 peach seasons. 'Carored', 'Flavorich', 'Springprince', and 'Zee Diamond' peach cultivars were not included in these analyses because of missing data. There were significant differences $(P \leq 0.05)$ across both years and cultivars for all texture measurements, hence mean comparisons hereafter are presented within each year for each firmness test (Table 3). Comparisons among replications for compression 1 and Kramer measurements within 2015 and 2016 were not significantly different

Table 3. Mean values of texture attributes for 26 commercial peach cultivars included in this study over two seasons.

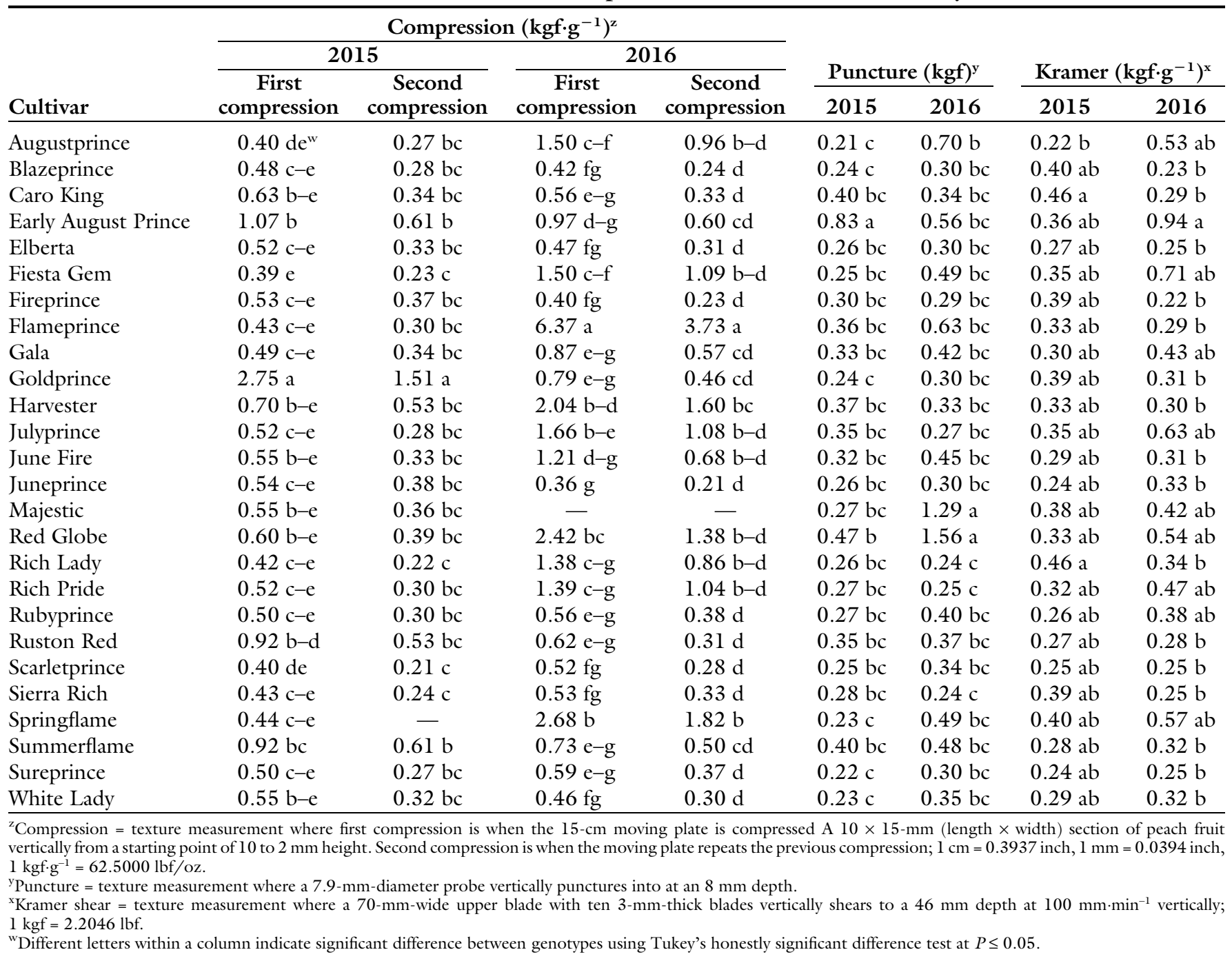




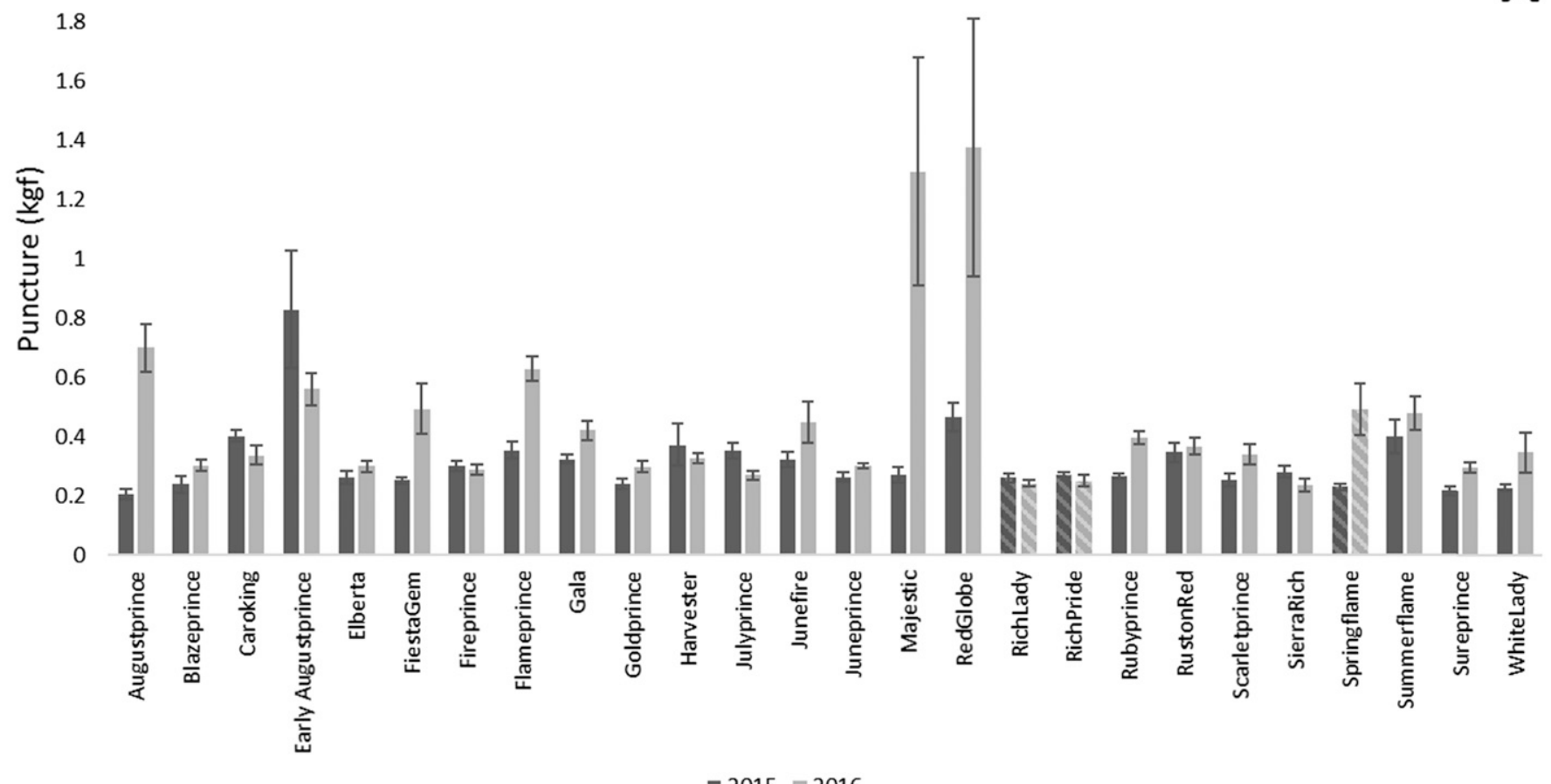

- $2015=2016$

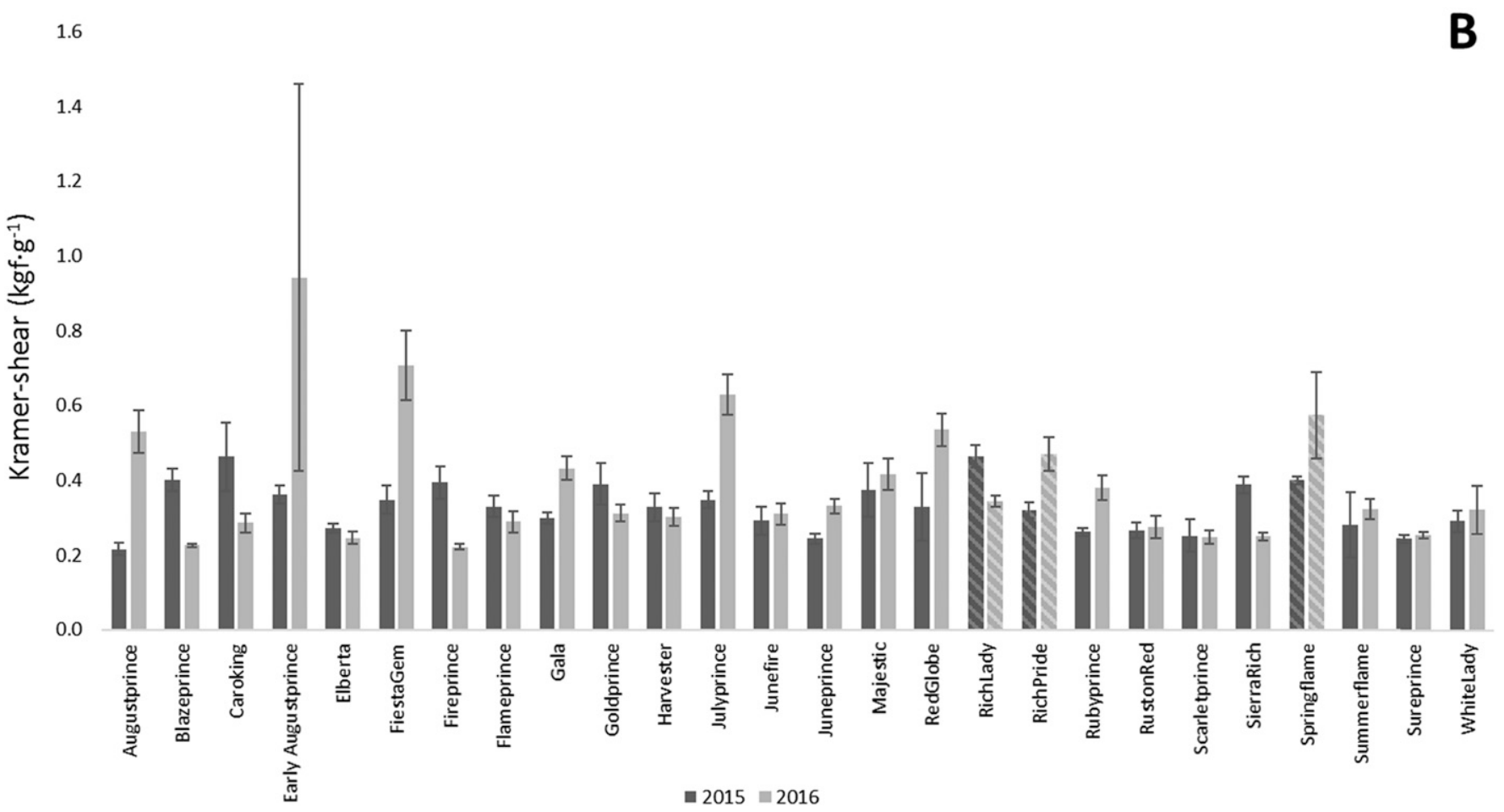

Fig. 1. Mean texture values and se for 26 commercial melting and non-melting peach cultivars grown in Georgia over two seasons. (A) Puncture measured where a $7.9-\mathrm{mm}$-diameter probe vertically punctured to at an $8 \mathrm{~mm}$ depth. (B) Kramer shear measured where a $70-\mathrm{mm}$-wide upper blade with ten 3 -mm-thick blades vertically shears, sheared to a $46 \mathrm{~mm}$ depth at $100 \mathrm{~mm} \cdot \mathrm{min}^{-1}$ vertically. (C) Compression measured where a $15-\mathrm{cm}$ moving plate compressed a $10 \times 15-\mathrm{mm}($ length $\times$ width $)$ section of peach fruit vertically from a starting point of $10 \mathrm{~mm}$ to a finishing height of $2 \mathrm{~mm}$. Values are presented as means of three to five replications. Dashed bars represent non-melting cultivars; $1 \mathrm{~mm}=0.0394 \mathrm{inch}, 1 \mathrm{~cm}=0.3937 \mathrm{inch}$, $1 \mathrm{kgf}=2.2046 \mathrm{lbf}, 1 \mathrm{kgf} \cdot \mathrm{g}^{-1}=62.5000 \mathrm{lbf} / \mathrm{oz}$.

$[P>0.05$ (data not shown)]. Comparisons among replications for other variables and within years were different
$[P \leq 0.05$ (data not shown)]. For compression and puncture, there were no significant differences when comparing measurements for blush and light side of the fruit $[P>0.05$ (data not shown)]. Hereafter, the 


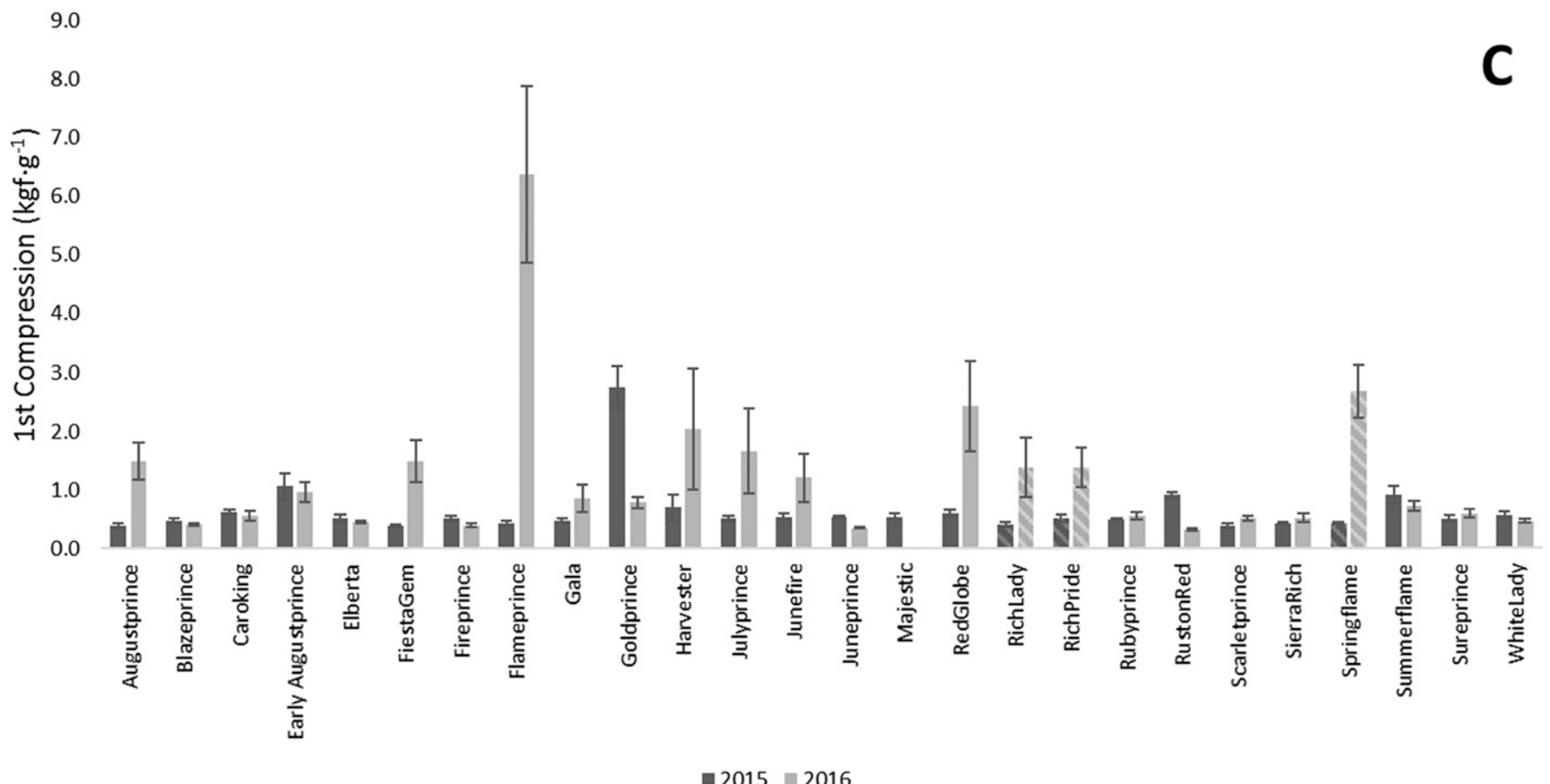

Fig. 1. (Continued)

results of blush and light side measurements were averaged per fruit (replication). For compression, there was a significant difference $(P \leq 0.05)$ when comparing the first compression vs. the second compression in 2015 $(P<0.0001)$ and $2016(P<0.0001)$.

First compression measurements ranged from $0.39 \mathrm{kgf \cdot g}{ }^{-1}$ for 'Fiesta Gem' to $2.75 \mathrm{kgf} \cdot \mathrm{g}^{-1}$ for 'Goldprince' in 2015 and $0.36 \mathrm{kgf} \cdot \mathrm{g}^{-1}$ for 'Juneprince' to $6.37 \mathrm{kgf} \cdot \mathrm{g}^{-1}$ for 'Flameprince' in 2016. These values represent hardness of the produce. As the fruit flesh is compressed, the force from the downward stroke increases and the maximum height is defined as hardness (Bourne, 1968). For the second compression, values ranged from $0.21 \mathrm{kgf \cdot \textrm {g } ^ { - 1 }}$ for 'Scarletprince'

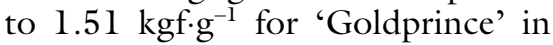
2015 , and from $0.21 \mathrm{kgf \cdot g} \mathrm{g}^{-1}$ for 'Juneprince' to $3.73 \mathrm{kgf} \cdot \mathrm{g}^{-1}$ for 'Flameprince' in 2016. The second compression is a measure of the elasticity and is defined by "the distance that the food recovers between first and second bites" (Bourne, 1968).

The puncture measurements ranged from $0.21 \mathrm{kgf}$ for 'Augustprince' to $0.83 \mathrm{kgf}$ for 'Early August Prince' in 2015 and from $0.24 \mathrm{kgf}$ for 'Rich Lady' and 'Sierra Rich' to $1.56 \mathrm{kgf}$ for 'Redglobe' in 2016. Puncture measures the "force and/or deformation to push a probe into a food product to a depth that causes irreversible damage" and is considered a standard measurement in fruit texture tests because of the widely known Magness and Taylor pressure test (Bourne, 1974). In Kramer shear, forces ranged from $0.22 \mathrm{kgf} \cdot \mathrm{g}^{-1}$ for 'Augustprince' to $0.46 \mathrm{kgf} \cdot \mathrm{g}^{-1}$ for 'Caroking' and 'Rich Lady' in 2015 and $0.22 \mathrm{kgf} \cdot \mathrm{g}^{-1}$ for 'Fireprince' to $0.94 \mathrm{kgf} \cdot \mathrm{g}^{-1}$ for 'Early August Prince' in 2016. Kramer shear measures a combination of multiple texture attributes including compression, shear, extrusion, and friction (Ahmed et al., 1972).

For cultivar-to-cultivar comparisons, compression, puncture, and Kramer shear, all the three methodologies captured the textural ranges variation among cultivars. Throughout all the tests, many of the cultivars had little variation between seasons, whereas some cultivars had extreme variation. In addition, cultivars with high firmness in one texture test were not necessarily the highest for the other two texture tests (Table 3). For instance, 'Goldprince' was high for compression $\left(2.75 \mathrm{kgf} \cdot \mathrm{g}^{-1}\right.$ in 2015 and $0.79 \mathrm{kgf} \cdot \mathrm{g}^{-1}$ in 2016) but not notably different for Kramer or puncture in that same year. For 'Early August Prince', values were high for Kramer $\left(0.36 \mathrm{kgf} \cdot \mathrm{g}^{-1}\right.$ in 2015 and
$0.94 \mathrm{kgf} \cdot \mathrm{g}^{-1}$ in 2016) but had a different trend for puncture and compression measurements.

Texture measurements were inconsistent for certain cultivars when comparing values across years (Figs. 1 and 2). These cultivars included Goldprince and Early August Prince in 2015; and Flameprince, Majestic, and Red Globe in 2016. Overall when comparing the different texture measurements, Kramer shear produced the lowest firmness values when compared with compression and puncture measurements, suggesting that the force to shear a sample is less than the force to puncture or compress the same sample. No clear trend between melting and non-melting cultivars with regard to firmness for all three texture tests was observed. Also, the variation observed for certain cultivars across seasons was inconsistent when comparing the different texture tests. These results could be due to differences in ripening time of the cultivars analyzed, various degrees of ripening at the time of the test, and differences in ripening rate between fruit replications and cultivars, among others. Ripe peaches are considered "ready-to-eat" with 0.9-1.4 kgf flesh firmness (Crisosto, 1999). However, the method of texture evaluation used to define this range is unknown. 

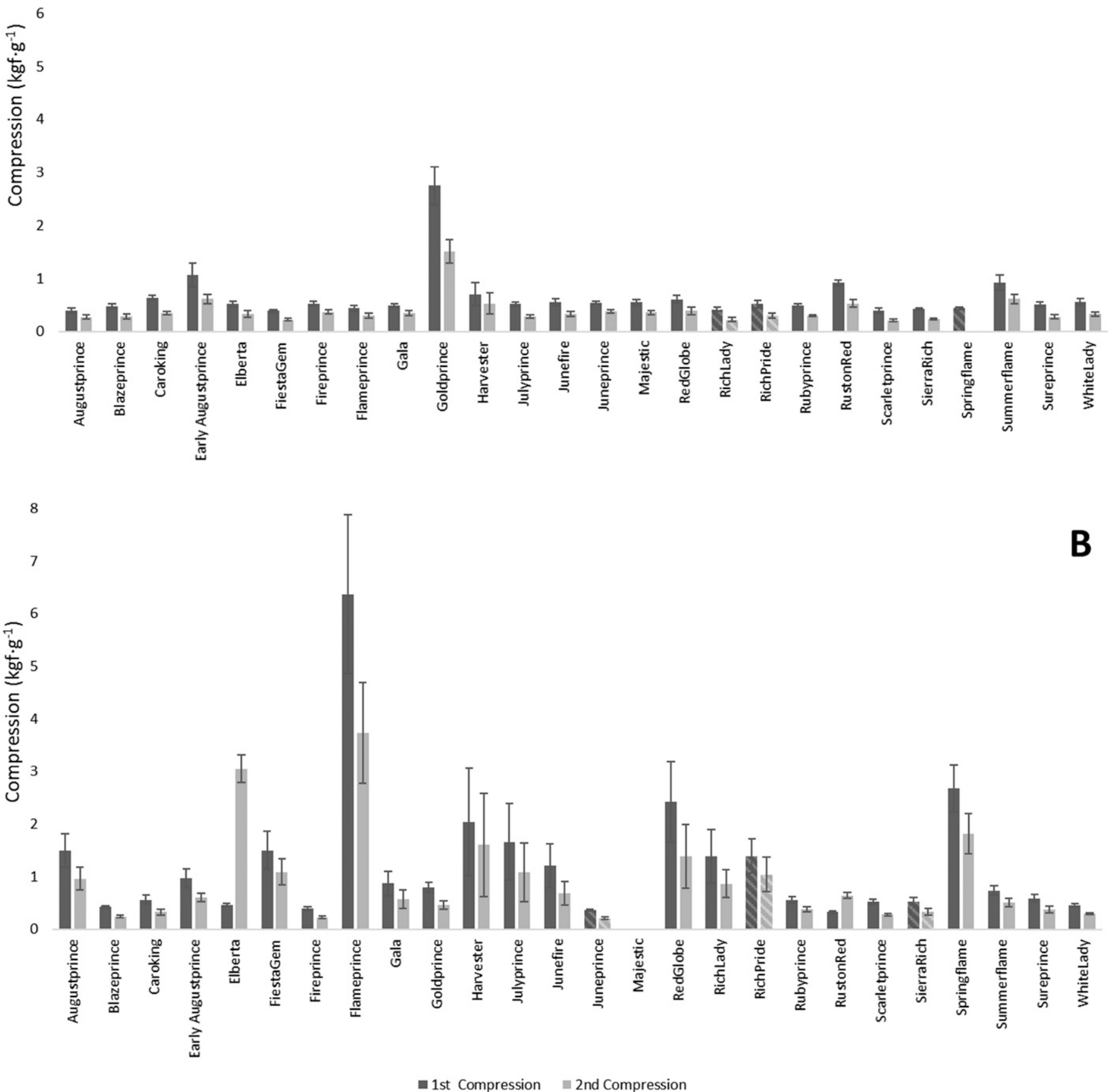

Fig. 2. Comparison of first compression and second compression in (A) 2015 and (B) 2016 peach seasons for 26 commercial melting and non-melting peach cultivars grown in Georgia over two seasons (Dashed bars represent non-melting cultivars.) Compression measured as the force used for a $15-\mathrm{cm}$ moving plate to compress $10 \times 15-\mathrm{mm}$ (length $\times$ width) section of peach fruit vertically from a starting point of 10 to $2 \mathrm{~mm}$ height. Mean values of five fruit replications with SE bars are reported; $1 \mathrm{~cm}=0.3937 \mathrm{inch}, 1 \mathrm{~mm}=0.0394 \mathrm{inch}, 1 \mathrm{kgf} \cdot \mathrm{g}^{-1}=62.5000 \mathrm{lbf} / \mathrm{oz}$.

CoLor. Skin and flesh color were evaluated for peaches in the 2015 and 2016 season. For skin, there were significant differences between years $(P<0.05)$ and cultivars $(P<0.0001)$ for $L^{*}$, chroma, and hue. For flesh, there were significant differences for years for $L^{*}$ and chroma $(P<0.0001)$. No significant differences were observed between years for flesh hue values $(P=0.38)$. For cultivars, there were statistical significant differences observed for $L^{*}(P<0.0001)$, chroma $(P<0.0001)$, and hue $(P<0.0001)$ flesh values. No significant differences 
were observed within each season for skin and flesh among replications for all color variables measured $[P>0.05$ (data not shown)]. Hereafter, all the analyses are based within a year comparisons, although, flesh hue values from year 2015 and 2016 did not show differences across years. Mean separation between cultivars are presented within each year (Tables 4 and 5 ).

In skin, $L^{*}$ values ranged from 32.89 for 'Springflame' to 76.06 for 'Julyprince' in 2015 and from 31.20 for 'Springflame' to 73.49 for 'Augustprince' in 2016 (Table 4). In chroma, values for skin ranged from 30.56 for 'Springflame' to 63.01 for 'Ruston Red' in 2015 and from 31.58 for 'Rich Lady' to 57.62 for 'Augustprince' in 2016. In hue, values ranged from 29.31 for 'Springflame' to 78.20 for 'Elberta' in 2015, and from 29.37 for 'White Lady' to 74.54 for 'Elberta' in 2016. The range in color space values suggests a large variation of individual and overall color in cultivars.
Independent of the base or ground color in peaches, indicated as $L^{*}$ and hue, the characteristics of red color, noted as values close to 0 for hue, are associated with the buildup of anthocyanins in the skin of peach. The accretion in peach skin's darkening hue is influenced by light exposure (Bassi and Monet, 2008) and accumulated mostly in later stages of ripening, thus has most often been associated with maturity (Byrne et al., 1991; Delwiche and Baumgardner, 1983, 1985; Kader et al., 1982; Rood, 1957).

For flesh values, $L^{*}$ ranged from 50.29 for 'Fiesta Gem' to 68.46 for 'Julyprince' in 2015 and from 56.05 for 'Fiesta Gem' to 91.62 for 'White Lady' in 2016 (Table 5). For chroma of flesh, values ranged from 22.80 for 'White Lady' to 58.11 for 'Springprince' in 2015 and from 34.65 for 'White Lady' to 88.27 for 'Ruston Red' in 2016. For hue, values ranged from 60.28 for 'Summerflame' to 89.59 'Julyprince' in 2015 and from 72.03 for 'Fiesta Gem' to 87.97 for
'White Lady' in 2016. In comparisons between the skin and flesh color space values, flesh had a higher $L^{*}$ compared with skin, suggesting there were more white hues in flesh. In hue, values had a greater range and were lower in the skin, suggesting that peach skin had greater red hues compared with the peach flesh. Lastly, chroma values were relatively equal between skin and flesh although there is not enough evidence to suggest that the saturation or vividness of the colors in skin and in flesh were directly associated with each other. The single white flesh cultivar evaluated, White Lady, had the lowest hue in comparison with all yellow-flesh cultivars. The lack of carotenoids in white flesh peaches causes the distinct white ground color. However, 'White Lady' was not highest in $L^{*}$. It is possible that the colorimeter was not able to pick up the lightness in $L^{*}$, however a combination of low chroma and hue suggest that the skin of 'White Lady' close to red with a dull color. Color

Table 4. Mean values for skin color attributes of 30 commercial peach cultivars included in this study over two seasons.

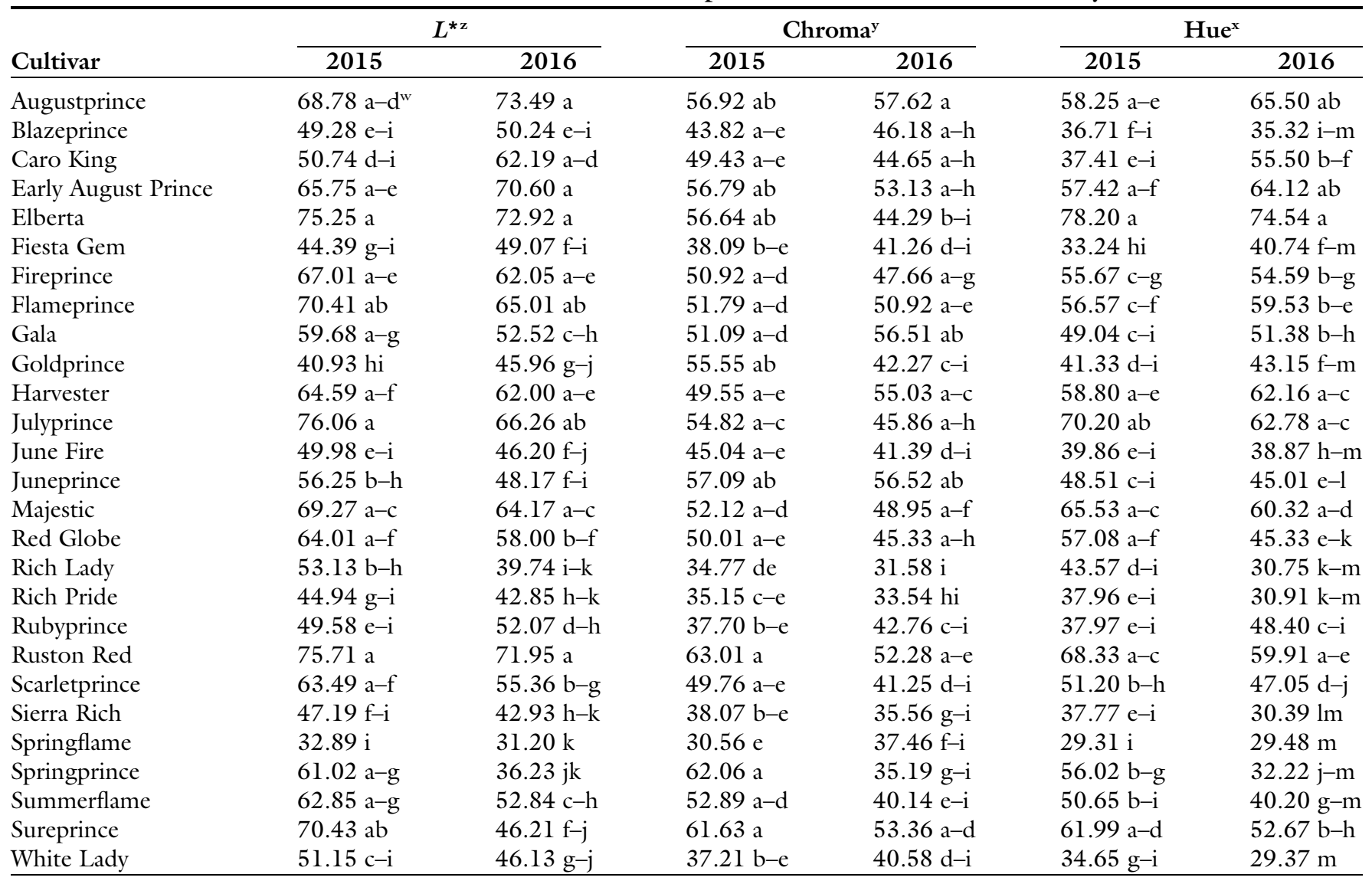

${ }^{\mathrm{z}} L^{*}$ values range from 0 (black) to 100 (white), represents lightness.

${ }^{\mathrm{y}}$ Chroma (saturation or vividness)-as chromaticity increases a color becomes more intense, as it decreases a color becomes duller.

${ }^{\mathrm{x}}$ Hue (tint of color)-an angular measurement where $0^{\circ}=$ red, $45^{\circ}=$ orange-red, $90^{\circ}=$ yellow, $180^{\circ}=$ green, and $270^{\circ}=$ blue .

${ }^{\mathrm{w}}$ Different letters within a column indicate significant difference between genotypes using Tukey's honestly significant difference test at $P \leq 0.05$. 
Table 5. Mean values for flesh color of 30 commercial peach cultivars included in this study over two seasons.

\begin{tabular}{|c|c|c|c|c|c|c|}
\hline \multirow[b]{2}{*}{ Cultivar } & \multicolumn{2}{|c|}{$L^{* \mathrm{z}}$} & \multicolumn{2}{|c|}{ Chroma $^{y}$} & \multicolumn{2}{|c|}{$\mathrm{Hue}^{\mathrm{x}}$} \\
\hline & 2015 & 2016 & 2015 & 2016 & 2015 & 2016 \\
\hline Augustprince & $56.59 \mathrm{~b}-\mathrm{d}^{\mathrm{w}}$ & $80.95 \mathrm{a}-\mathrm{f}$ & $53.44 \mathrm{a}-\mathrm{e}$ & $74.40 \mathrm{~b}-\mathrm{d}$ & $70.13 \mathrm{~b}-\mathrm{d}$ & $74.58 \mathrm{c}-\mathrm{f}$ \\
\hline Caro King & $62.23 \mathrm{ab}$ & $78.51 \mathrm{~b}-\mathrm{g}$ & $47.72 \mathrm{a}-\mathrm{g}$ & $60.68 \mathrm{e}-\mathrm{h}$ & $82.16 \mathrm{ab}$ & $86.80 \mathrm{ab}$ \\
\hline Early August Prince & $60.22 \mathrm{a}-\mathrm{c}$ & $84.62 \mathrm{a}-\mathrm{d}$ & $54.16 \mathrm{a}-\mathrm{d}$ & $77.27 \mathrm{a}-\mathrm{c}$ & $74.28 \mathrm{a}-\mathrm{d}$ & $77.83 \mathrm{a}-\mathrm{f}$ \\
\hline Elberta & $62.08 \mathrm{ab}$ & $88.35 \mathrm{ab}$ & $52.00 \mathrm{a}-\mathrm{f}$ & $76.34 \mathrm{bc}$ & $85.98 \mathrm{ab}$ & $85.99 \mathrm{ab}$ \\
\hline Flameprince & $56.48 \mathrm{~b}-\mathrm{d}$ & $86.38 \mathrm{a}-\mathrm{c}$ & $39.97 \mathrm{~g}$ & $83.67 \mathrm{ab}$ & $64.48 \mathrm{~cd}$ & $74.02 \mathrm{~d}-\mathrm{f}$ \\
\hline Gala & $64.62 \mathrm{ab}$ & $78.08 \mathrm{~b}-\mathrm{g}$ & $48.32 \mathrm{a}-\mathrm{g}$ & $69.54 \mathrm{c}-\mathrm{e}$ & $83.55 \mathrm{ab}$ & $86.85 \mathrm{ab}$ \\
\hline Goldprince & $59.61 \mathrm{a}-\mathrm{d}$ & $62.53 \mathrm{i}-\mathrm{k}$ & $48.85 \mathrm{a}-\mathrm{g}$ & $50.02 \mathrm{~h}$ & $80.88 \mathrm{ab}$ & $83.42 \mathrm{a}-\mathrm{e}$ \\
\hline Harvester & $61.73 \mathrm{ab}$ & $79.87 \mathrm{~b}-\mathrm{f}$ & $44.39 \mathrm{c}-\mathrm{g}$ & $66.52 \mathrm{c}-\mathrm{e}$ & $85.65 \mathrm{ab}$ & $83.88 \mathrm{a}-\mathrm{e}$ \\
\hline Julyprince & $68.46 \mathrm{a}$ & $72.64 \mathrm{e}-\mathrm{i}$ & $50.09 \mathrm{a}-\mathrm{g}$ & $51.53 \mathrm{gh}$ & $89.59 \mathrm{a}$ & $84.83 \mathrm{a}-\mathrm{c}$ \\
\hline Rich Lady & $65.77 \mathrm{ab}$ & $74.52 \mathrm{~d}-\mathrm{h}$ & $43.06 \mathrm{e}-\mathrm{g}$ & $61.45 \mathrm{e}-\mathrm{g}$ & $85.15 \mathrm{ab}$ & $85.36 \mathrm{ab}$ \\
\hline Rich Pride & $58.68 \mathrm{a}-\mathrm{d}$ & $71.00 \mathrm{f}-\mathrm{j}$ & $47.34 \mathrm{~b}-\mathrm{g}$ & $64.44 \mathrm{~d}-\mathrm{f}$ & $79.67 \mathrm{a}-\mathrm{c}$ & $74.06 \mathrm{~d}-\mathrm{f}$ \\
\hline Rubyprince & $61.86 \mathrm{ab}$ & $65.75 \mathrm{~h}-\mathrm{k}$ & $46.49 \mathrm{~b}-\mathrm{g}$ & $54.70 \mathrm{f}-\mathrm{h}$ & $79.64 \mathrm{a}-\mathrm{c}$ & $83.13 \mathrm{a}-\mathrm{e}$ \\
\hline Ruston Red & $62.47 \mathrm{ab}$ & $85.95 \mathrm{a}-\mathrm{c}$ & $56.79 \mathrm{ab}$ & $88.27 \mathrm{a}$ & $87.60 \mathrm{a}$ & $82.21 \mathrm{a}-\mathrm{f}$ \\
\hline Scarletprince & $62.59 \mathrm{ab}$ & $73.14 \mathrm{e}-\mathrm{i}$ & $43.83 \mathrm{~d}-\mathrm{g}$ & $52.38 \mathrm{gh}$ & $87.52 \mathrm{a}$ & $84.59 \mathrm{a}-\mathrm{d}$ \\
\hline Sierra Rich & $58.91 \mathrm{a}-\mathrm{d}$ & $77.71 \mathrm{~b}-\mathrm{g}$ & $53.25 \mathrm{a}-\mathrm{e}$ & $67.45 \mathrm{c}-\mathrm{e}$ & $81.06 \mathrm{ab}$ & $82.74 \mathrm{a}-\mathrm{f}$ \\
\hline Springflame & $57.10 \mathrm{~b}-\mathrm{d}$ & $61.64 \mathrm{jk}$ & $52.44 \mathrm{a}-\mathrm{f}$ & $62.20 \mathrm{e}-\mathrm{g}$ & $79.72 \mathrm{a}-\mathrm{c}$ & $85.26 \mathrm{a}-\mathrm{c}$ \\
\hline Springprince & $67.48 \mathrm{a}$ & $70.83 \mathrm{f}-\mathrm{j}$ & $58.11 \mathrm{a}$ & $62.42 \mathrm{e}-\mathrm{g}$ & $79.74 \mathrm{a}-\mathrm{c}$ & 73.48 ef \\
\hline Summerflame & $50.92 \mathrm{~cd}$ & $84.68 \mathrm{a}-\mathrm{d}$ & $48.34 \mathrm{a}-\mathrm{g}$ & $75.93 \mathrm{bc}$ & $60.28 \mathrm{~d}$ & $78.93 \mathrm{a}-\mathrm{f}$ \\
\hline Sureprince & $60.00 \mathrm{a}-\mathrm{d}$ & $68.59 \mathrm{~g}-\mathrm{j}$ & $46.58 \mathrm{~b}-\mathrm{g}$ & $67.22 \mathrm{c}-\mathrm{e}$ & $79.00 \mathrm{a}-\mathrm{c}$ & $76.28 \mathrm{~b}-\mathrm{f}$ \\
\hline White Lady & $65.97 \mathrm{ab}$ & $91.62 \mathrm{a}$ & $22.80 \mathrm{~h}$ & $34.65 \mathrm{i}$ & $87.66 \mathrm{a}$ & $87.97 \mathrm{a}$ \\
\hline
\end{tabular}

${ }^{\mathrm{z}} L^{*}$ values range from 0 (black) to 100 (white), represents lightness.

${ }^{y}$ Chroma (saturation or vividness)-as chromaticity increases a color becomes more intense, as it decreases a color becomes duller.

${ }^{\mathrm{x}}$ Hue (tint of color) - an angular measurement where $0^{\circ}=$ red, $45^{\circ}=$ orange-red, $90^{\circ}=$ yellow, $180^{\circ}=$ green, and $270^{\circ}=$ blue .

${ }^{w}$ Different letters within a column indicate significant difference between genotypes using Tukey's honestly significant difference test at $P \leq 0.05$

values have been used as indicators of maturity, such as by Kader et al. (1982) in which $a^{*}$, redness, was used to measure maturity.

CORRELATIONS BETWEEN VARIABLES. Tables 6 and 7 show the correlation coefficients of each variable and between years. Soluble solids concentration, TTA, SSC/TTA ratio along with skin ( $L^{*}$, chroma, hue) and flesh color space values (hue and chroma) were positively correlated across both seasons (Table 6). This suggested that among a large selection of cultivars, these are the most stable quality measurements across seasons and more likely less affected by the environment. However, compression, puncture, and Kramer, along with $L^{*}$ of flesh, showed no correlations between seasons. This suggested that the texture values were not consistent between seasons and more likely were affected by the environment and the natural variation present for each peach cultivar. Stability of traits can be advantageous in future breeding lines and material to be used by the industry as standards.

The SSC/TTA ratio values across the cultivars and seasons were compared. SSC/TTA ratios between peach seasons for 2015 and for 2016 were highly correlated $[r=0.86$ (Table 6)]. As expected, SSC/TTA ratio was moderate positively correlated with SSC in $2015(r=0.42)$ and in $2016(r=0.48)$. The SSC/TTA ratio was strongly negatively correlated with TTA in $2015(r=-0.79)$ and in $2016(r=-0.84)$ (Table 7). Several studies have previously reported this pattern in peaches as an explanation of the gradual decline of TTA as peaches ripen (Bakshi and Masoodi, 2009; Kwon et al., 2007; Moing et al., 1998).

The ranges for texture measurements per cultivar in 2016 were slightly higher than in 2015. For compression, two force peaks (bites) were measured. Both values, first and second compressions, were highly positively correlated in 2015 and $2016[r=0.99$ (Table 7)]. For puncture and Kramer shear, significant correlations were not found between years. Bourne (1974) suggested that compression contributes to force more so than Kramer shear. As previously tested by Bourne (1974), we compared puncture, Kramer, and compression tests to understand the texture characteristics of different peach cultivars (data not shown). The relationship when comparing compression and puncture values within each season were captured using a linear fit in $2015\left[R^{2}{ }_{2015}=\right.$ $0.376, P=0.001$ (data not shown)]. The relationship when comparing compression and puncture in 2016 were not significant $(P=0.17)$. The low regression coefficient in 2015 and lack of fit in 2016 is likely due to variation in fruit maturity within each cultivar, the ripening rate differences among the cultivars, and the inherit differences between the textural tests used. There were no significant linear relationships between Kramer and 
Table 6. Observable attributes compared between two harvest seasons using Pearson's Pairwise correlations of $\mathbf{3 0}$ commercial peach cultivars grown in Georgia. Only statistically significant correlations are shown.

\begin{tabular}{llcc}
\hline Variable $1^{\mathrm{z}}$ & \multicolumn{1}{c}{ Variable 2 } & Correlation $(r)$ & Pvalue \\
\hline Skin $L^{\star} 2015$ & Skin $L^{*} 2016$ & 0.76 & $<0.0001$ \\
Skin hue 2015 & Skin hue 2016 & 0.79 & $<0.0001$ \\
Skin chroma 2015 & Skin chroma 2016 & 0.61 & 0.001 \\
Flesh hue 2015 & Flesh hue 2016 & 0.62 & 0.001 \\
Flesh chroma 2015 & Flesh chroma 2016 & 0.56 & 0.004 \\
SSC 2015 & SSC 2016 & 0.48 & 0.018 \\
TTA 2015 & TTA 2016 & 0.50 & 0.012 \\
SSC/TTA 2015 & SSC/TTA 2016 & 0.86 & $<0.0001$ \\
\hline
\end{tabular}

${ }^{\mathrm{z}} L^{*}$ values range from 0 (black) to 100 (white), represents lightness; chroma (saturation or vividness)-as chromaticity increases a color becomes more intense, as it decreases a color becomes duller; hue (tint of color)-an angular measurement where $0^{\circ}=$ red, $45^{\circ}=$ orange-red, $90^{\circ}=$ yellow, $180^{\circ}=$ green, and $270^{\circ}=$ blue $;$ SSC $=$ soluble solids concentration; TTA $=$ total titratable acidity.

Table 7. Observable attributes compared within a harvest seasons for 2 years using Pearson's Pairwise correlations of 30 commercial peach cultivars grown in Georgia. Only statistically significant correlations are shown.

\begin{tabular}{|c|c|c|c|}
\hline Variable 1 & Variable 2 & Correlation $(r)$ & $P$ value \\
\hline \multicolumn{4}{|l|}{2015 correlations $^{\mathrm{z}}$} \\
\hline Skin hue & Skin chroma & 0.77 & $<0.0001$ \\
\hline Skin chroma & Kramer & -0.41 & 0.047 \\
\hline \multirow[t]{3}{*}{ SSC/TTA } & TTA & -0.79 & $<0.0001$ \\
\hline & SSC & 0.42 & 0.040 \\
\hline & Flesh chroma & -0.42 & 0.039 \\
\hline First compression ${ }^{\mathrm{y}}$ & Second compression & 0.99 & $<0.0001$ \\
\hline \multicolumn{4}{|l|}{2016 correlations } \\
\hline \multirow[t]{2}{*}{ Skin hue } & Skin chroma & 0.72 & $<0.0001$ \\
\hline & Flesh chroma & 0.50 & 0.013 \\
\hline Skin chroma & Flesh chroma & 0.47 & 0.020 \\
\hline \multirow[t]{2}{*}{ SSC/TTA } & TTA & -0.84 & $<0.0001$ \\
\hline & SSC & 0.48 & 0.017 \\
\hline \multirow[t]{3}{*}{ SSC } & Puncture & 0.48 & 0.017 \\
\hline & Second compression & 0.50 & 0.013 \\
\hline & First compression & 0.56 & 0.005 \\
\hline First compression & Second compression & 0.99 & $<0.0001$ \\
\hline
\end{tabular}

puncture with regression coefficients for $2015\left(R^{2}=0.016\right)$ and $2016\left(R^{2}=0.195\right)$ (data not shown). In studying textural changes in ripening peaches, Bourne (1974) reported a positive linear relationship between compression and puncture, but not between Kramer and puncture tests, suggesting that "compression contributed to the major part of the puncture force," whereas Kramer and puncture do not (lack of linear relationship). In addition, compression could capture a greater variation of textural changes than Kramer was able. According to Bourne (1974), when fruits are selected in varying ripeness stages, puncture, compression, and Kramer shear could be used interchangeably. However, because fruit from each cultivar was obtained from a commercial peach producer, having all fruit be exactly at the same stage and be categorized as such proved difficult. Our results do not show clear trends across seasons for all the texture methods studied; however, textural differences suggest variation among cultivars and variation found across testing methods.

Color space for peach skin, $L^{*}$, hue, and chroma were highly correlated when comparing cultivars between years $\left[r_{L^{*}}=0.76, r_{\text {hue }}=0.79\right.$, $r_{\text {chroma }}=0.61($ Table 6) $]$. Similarly, flesh color space of chroma and hue were correlated when comparing cultivars between years $\left[r_{\text {chroma }}=0.62\right.$, $r_{\text {hue }}=0.56($ Table 6$\left.)\right]$. No significant correlation was observed between 2015 and 2016 for flesh color space value $L^{*}$. Anthocyanin content and genotypic differences of the peach cultivars can explain variation in $L^{*}$ values. Higher $L^{*}$ values represent a higher degree of lightness. As anthocyanin develops in peaches, a redder hue appears and the lightness values decrease (Frett et al., 2014). Significant correlations between skin hue and chroma were observed in $2015(r=0.77)$ and $2016(r=0.72)$ (Table 7). Peaches are characteristic for their light hue ground color, often being yellow to orange. Pigment variation demonstrated observable differences among peach genotypes, which can be impacted by environmental factors, mainly shade and exposure to sunlight (Bible and Singha, 1993).

In our study, correlations between data for SSC, and puncture, first and second compression were reported in 2016 season (Table 7 ). However, in 2015 color correlations were found for Kramer and skin chroma. Genard and Bruchou (1992) reported that color variation is almost independent of firmness and the biochemical composition in a peach fruit, whereas SSC and TTA have been correlated strongly with firmness (Delgado et al., 2013). Our results show a slightly positive correlation between compression values and skin chroma, representing the saturation and vividness of a color. Several physiological changes characterize fruit ripening. Some of these changes include the slight increase of SSC, decrease in TTA, softening of textures, and development of red pigment. In addition, across the peach season there was a positive relationship between SSC increasing at later harvest dates $\left[R^{2}{ }_{2015}=0.431 ; R^{2}{ }_{2016}=\right.$ 0.692 (data not shown)]. This could be due to longer fruit development periods for late cultivars, which allow compounds to accumulate in the fruit for a longer period in comparison with early fruit cultivars.

\section{Conclusions}

A survey of quality variation among commercial peach cultivars should allow researchers to better 
select cultivars based on quality. It should be kept in mind that in addition to cultivar-to-cultivar variation; year-to-year variation was prominent in textures, SSC, and SSC/TTA ratio; this suggests that these values are sensitive to environmental impacts, including maturity and harvest location, and management impacts, such as packing procedures and storage time. However, flesh hue values and TTA were relatively constant.

In addition, the market demand for high quality is becoming more apparent and it is being defined by consumers now more than it has been in the past 50 years. Research to evaluate the effects of such quality characteristics with regard to their perception and liking is the next step in understanding quality attributes of peaches. Texture values need to be compared with descriptive sensory analysis to determine the most practical physical measurement as compared with sensory perception. In addition, the data generated may be used to select cultivars for future studies based on quality attributes.

\section{Literature cited}

Ahmed, E.M., R.A. Dennison, and R.C. Fluck. 1972. Textural properties of stored and irradiated peaches: I. Firmness. J. Texture Stud. 3:310-318.

Bakshi, P. and F.A. Masoodi. 2009. Effect of various storage conditions on chemical characteristics and processing of peach $\mathrm{cv}$. 'Flordasun'. J. Food Sci. Technol. 46: 271-274.

Baldwin, E.A. 2002. Fruit flavor, volatile metabolism and consumer perceptions, p. 89-106. In: M. Knee (ed.). Fruit quality and its biological basis. CRC Press, Boca Raton, FL.

Bassi, D. and R. Monet. 2008. Botany and taxonomy, p. 1-30. In: D.R. Layne and D. Bassi (eds.). The peach: Botany, production and uses. CAB Intl., Cambridge, MA.

Bassi, D. and R. Selli. 1990. Evaluation of fruit quality in peach and apricot. Adv. Hort. Sci. 4:107-112.

Bible, B.B. and S. Singha. 1993. Canopy position influences CIELAB coordinates of peach color. HortScience 28:992993.

Bourne, M.C. 1968. Texture profile of ripening pears. J. Food Sci. 33:223-226.

Bourne, M.C. 1974. Textural changes in ripening peaches. Can. Inst. Food Sci. Technol. J. 7:11-15.
Brovelli, E.A., J.K. Brecht, W.B. Sherman, C.A. Sims, and J.M. Harrison. 1999. Sensory and compositional attributes of melting- and non-melting-flesh peaches for the fresh market. J. Sci. Food Agr. 79:707-712.

Bruhn, C.M. 1995. Consumer and retailer satisfaction with the quality and size of California peaches and nectarines. J. Food Qual. 18:241-256.

Bruhn, C.M., N. Feldman, C. Garlitz, J. Harwood, E. Ivans, M. Marshall, A. Riley, D. Thurber, and E. Williamson. 1991. Consumer perceptions of quality: Apricots, cantaloupes, peaches, pears, strawberries, and tomatoes. J. Food Qual. 14:187-195.

Byrne, D.H., A.N. Nikolic, and E.E. Burns. 1991. Variability in sugars, acids, firmness, and color characteristics of 12 peach genotypes. J. Amer. Soc. Hort. Sci. 116:1004-1006.

Cantín, C.M., Y. Gogorcena, and M.Á. Moreno. 2009. Analysis of phenotypic variation of sugar profile in different peach and nectarine [Prunus persica (L.) Batsch] breeding progenies. J. Sci. Food Agr. 89:1909-1917.

Cirilli, M., D. Bassi, and A. Ciacciulli. 2016. Sugars in peach fruit: A breeding perspective. Hort. Res. 3:15067.

Colaric, M., R. Veberic, F. Stampar, and M. Hudina. 2005. Evaluation of peach and nectarine fruit quality and correlations between sensory and chemical attributes. J. Sci. Food Agr. 85:2611-2616.

Contador, L., P. Rubio, P. Shinya, C. Menese, A. Pena-Neira, and R. Infante. 2011. Phenolics contents and sensory characterization of melting and non-melting peach. J. Hort. Sci. Biotechnol. 86:255-260.

Contador, L., P. Shinya, M. Diaz, E. Hernaindez, and R. Infante. 2015. Evaluation of textural properties of peach and nectarine through texture profile analysis. Acta Hort. 1079:633-636.

Crisosto, C.H. 1999. Optimum procedures for ripening stone fruit. Univ. California, Davis, Postharvest Hort. Series 9:28-30.

Crisosto, C.H. and G.M. Crisosto. 2005. Relationship between ripe soluble solids concentration and consumer acceptance of high and low acid melting flesh peach and nectarine (Prunus persica (L.) Batsch) cultivars. Postharvest Biol. Technol. 38:239-246.

Crisosto, C.H., G.M. Crisosto, G. Echeverria, and J. Puy. 2006. Segregation of peach and nectarine (Prunus persica (L.) Batsch) cultivars according to their organoleptic characteristics. Postharvest Biol. Technol. 39:10-18.
Crisosto, C.H. and D. Valero. 2008. Harvesting and postharvest handling of peaches for the fresh market, p. 536-549. In: D.R. Layne and D. Bassi (eds.). The peach: Botany, production and uses. $\mathrm{CAB}$ Intl., Cambridge, MA.

Culpepper, C.W. and J.S. Caldwell. 1930. The canning quality of certain commercially important eastern peaches. U.S. Dept. Agr. Tech. Bul. 196.

Delgado, C., G.M. Crisosto, H. Heymann, and C.H. Crisosto. 2013. Determining the primary drivers of liking to predict consumers' acceptance of fresh nectarines and peaches. J. Food Sci. 78:S605S614.

Delwiche, M.J. and R.A. Baumgardner. 1983. Ground color measurements of peach. J. Amer. Soc. Hort. Sci. 108:1012-1016.

Delwiche, M.J. and R.A. Baumgardner. 1985. Ground color as a peach maturity index. J. Amer. Soc. Hort. Sci. 110:53-57.

Diehl, D.C., N.L. Sloan, C.M. Bruhn, A.H. Simonne, J.K. Brecht, and E.J. Mitcham. 2013. Exploring produce industry attitudes: Relationships between postharvest handling, fruit flavor, and consumer purchasing. Hort Technology 23:642-650.

Echeverria, G., J. Cano, L. Lopez, and G. Alins. 2012. Influence of volatile compound emissions and standard quality on consumer acceptance of peaches and nectarines. Acta Hort. 934:1075-1081.

Esti, M., M.C. Messia, F. Sinesio, A. Nicotra, L. Conte, E. La Notte, and G. Palleschi. 1997. Quality evaluation of peaches and nectarines by electrochemical and multivariate analyses: Relationships between analytical measurements and sensory attributes. Food Chem. 60:659-666.

Etienne, C., C. Rothan, A. Moing, C. Plomion, C. Bodénès, L. SvanellaDumas, P. Cosson, V. Pronier, R. Monet, and E. Dirlewanger. 2002. Candidate genes and QTLs for sugar and organic acid content in peach [Prunus persica (L.) Batsch]. Theor. Appl. Genet. 105:145-159.

Fallahi, E., B. Fallahi, B. Shafii, and M.E. Amiri. 2009a. Bloom and harvest dates, fruit quality attributes, and yield of modern peach cultivars in the intermountain western United States. HortTechnology 19:823-830.

Fallahi, E., B. Fallahi, B. Shafii, M.E. Amiri, and M. Mirjalili. 2009b. Growing degree days, bloom and harvest dates, fruit quality and yield of new yellow and white nectarines. J. Amer. Pomol. Soc. 63:150-159.

Frett, T.J., G.L. Reighard, W.R. Okie, and K. Gasic. 2014. Mapping quantitative trait loci associated with blush in peach 
[Prunus persica (L.) Batsch]. Tree Genet. Genomes 10:367-381.

Genard, M. and C. Bruchou. 1992. Multivariate analysis of within-tree factors accounting for the variation of peach fruit quality. Scientia Hort. 52:37-51.

Hilaire, C. 2003. The peach industry in France: State of art, research and development. Proc. First Mediterranean Peach Symp. 1:27-34

Kader, A.A. 1995. Fruit maturity, ripening, and quality relationships. Perishables Handling Nwsl. 80:2.

Kader, A.A. 2002. Postharvest technology of horticultural crops. 3rd ed. Univ. California ANR Publ. 3311.

Kader, A.A., C.M. Heinta, and A. Chordas. 1982. Post-harvest quality of fresh and canned clingstone peaches as influenced by genotypes and maturity at harvest. J. Amer. Soc. Hort. Sci. 107:947-951.

Kwon, J.H., J.H. Jun, and H.J. Lee. 2007. Changes in sugar composition and related enzyme activities during fruit development in 'Kansuke Hakuto' and 'Kurakatawase' peach (Prunus persica). Hort. Environ. Biotechnol. 48:235-240.

Lopez, G., M.H. Behboudian, G. Echeverria, M. Mata, J. Girona, and J. Marsal. 2011. Instrumental and sensory evaluation of fruit quality for 'Ryan's Sun' peach grown under deficit irrigation. HortTechnology 21:712-719.

Mitcham, B., M. Cantwell, and A. Kader. 1996. Methods for determining quality of fresh commodities. Perishables Handling Nwsl. 85:1-5.

Moing, A., L. Svanella, D. Rolin, M. Gaudillere, J.P. Gaudillere, and R. Monet. 1998. Compositional changes during the fruit development of two peach cultivars differing in juice acidity. J. Amer. Soc. Hort. Sci. 123:770-775.

Ortiz, A., I. Lara, J. Graell, M.L. Lopez, and G. Echeverria. 2008. Sensory acceptance of CA-stored peach fruit. Relationship to instrumental quality parameters. Acta Hort. 796:225-230.

Peynaud, E. 1950. Sur la composition chimique des pêches. Ann. Agron. 1:775791.

Rood, P. 1957. Development and evaluation of objective maturity indices for California freestone peaches. Proc. Amer. Soc. Hort. Sci. 70:104-112.

Ryugo, K. and L.D. Davis. 1958. Seasonal changes in acid content fruits and leaves of selected peach and nectarine clones. Proc. Amer. Soc. Hort. Sci. 72:106-112.

Sanz, C. and A.G. Perez. 2010. Plant metabolic pathways and flavor biosynthesis, p. 129-156. In: Y.H. Hui, F. Chen, and L.M. Nollet (eds.). Hdbk fruit and vegetable flavors, Vol. 1. Wiley, Hoboken, NJ.

Shinya, P., L. Contador, S. Predieri, P. Rubio, and R. Infante. 2013. Peach ripening: Segregation at harvest and postharvest flesh softening. Postharvest Biol. Technol. 86:472-478.
Souty, M., A. Perret, and P. Andre. 1967. Premières observations sur quelques variétiés de pêches destinées à la conserve. Ann. Technol. Agr. 16:55-68.

Testoni, A. 1995. Momento di racolta, qualita, condizionamento e confezionamento delle pesche. Proc. Symp. la Peschicoltura Veronesa alle Soglie del 2000, Verona, Italy. p. 327-354.

U.S. Department of Agriculture. 2016. U.S. per capita use, production and value, bearing acreage, cash receipts, price, and marketing spreads. 19 Jan. 2017. <https://www.ers.usda.gov/dataproducts/fruit-and-tree-nut-data/ yearbook-tables/>.

U.S. Department of Agriculture. 2017. Noncitrus fruits and nuts. 2016 summary. 19 Jan. 2017. <http://usda.mannlib. cornell.edu / u sda / current / NoncFruiNu/NoncFruiNu-06-272017.pdf>.

Ventura, M., A. Sama, A. Minguzzi, S. Lanzon, and S. Sansavini. 2000. Ottimizzazione del carico di fruit per migliorare la produzione e la qualita delle nectarine Supercrimson e Venus. Proc. XXIV Convengo Peschiolo 1:173176.

Visai, C. and M. Vanoli. 1997. Volatile compound production during growth and ripening of peaches and nectarines. Scientia Hort. 70:15-24. 